\title{
INNOVATION ACTIVITY MANAGEMENT OF ENTERPRISES UNDER SELF-DEVELOPMENT
}

\author{
Marharyta Berdar ${ }^{1}$, Olha Yevtushevska²
}

\begin{abstract}
There are the research directions, determined as relevant, such as the issues of innovation activity management of enterprises, identifying the main causes of low innovation activity of domestic companies, improving the innovation activity management system of industrial institutions, which necessitates the formation of a scientific and methodological basis that can realize the ability to describe the process of innovation activity of the enterprises and mechanisms to manage them. These issues are also relevant because in the context of strengthening the course on European integration, the management of domestic enterprises is tasked with identification of the methodological and practical experience of innovative management of the EU countries as soon as possible and harmonization of their policies in accordance with its provisions. The subject of the study is complex research of management of innovative activity of enterprises under self-development. The purposes of the article are a study of the main directions of operation of innovative-active enterprise under self-development; analysis of key indicators of innovation activity of an enterprise; characteristic of the mechanism of innovation activity management of an enterprise in terms of self-development; definition of directions of policy of strengthening of innovation activity with the purpose of increase of efficiency of development of domestic enterprises. To achieve these purposes the following research methods are used: analysis and generalization of theoretical sources and scientific literature; abstract-logical method in the process of theoretical generalizations and formation of conclusions; prognostic and diagnostic; general scientific methods of analysis and synthesis. Results. The article describes the concept of innovation activity of the enterprise and details its main elements. The authors have also formulated the concept of innovative-active enterprise and presented the priority directions of its operation. The basic aspects of improvement of the innovation activity management system of the enterprise under self-development are considered. The key aspects of improving the management system are highlighted: analysis and evaluation of changes in the operation of the enterprise (evaluation of innovation activity); choice of direction of innovative development of the enterprise; development of strategy of innovative operation (definition of priority of directions, their correlation, development of scenarios); control of implementation of the enterprise development strategy. The process of improving the system of management of innovative activity of the enterprise under self-development is presented as a block diagram. The process is considered and the mechanism of innovation activity management is proposed. Practical implications. The article presents the process of managing innovation activity according to the degree of selfdevelopment of the enterprise. The proposed mechanism has practical orientation in forming a set of measures for strategic development of the enterprise. In general, the paper outlines the main tasks for improving the innovation activity management system, the solutions of which will improve the effective functioning of the enterprise.
\end{abstract}

Key words: innovation activity, self-development, management system, enterprise, innovation operation, development, efficiency.

JEL Classification: $\mathrm{O} 31, \mathrm{M} 11, \mathrm{H} 21$

\section{Introduction}

Managing enterprise innovation activity as a complex socio-economic system is increasingly focused on self-development, on the reproduction and mobilization of internal potential, competitive efficiency, systematicity and synergy. The problems of managing the self-development of the enterprise are the subject of numerous theoretical and applied researches. In scientific sources and literature highlighting the successful practice of managing the enterprise's self-

\footnotetext{
Corresponding author:

${ }^{1}$ Taras Shevchenko National University of Kyiv, Ukraine.

E-mail: berdar-1@ukr.net

${ }^{2}$ Taras Shevchenko National University of Kyiv, Ukraine.

E-mail: evtush5221@i.ua
} 
development, many definitions of self-developing enterprise and approaches to self-development management are offered. From the point of view of the systematic approach, the economic category and the object of management of "innovative self-developing enterprise" are defined by us as the enterprise capable to independently and autonomously reproduce on the innovative basis the organization of new quality, characterized by special integrity, providing it with a stable competitive advantage and strategic readiness in an adequate and timely manner to respond to market challenges. Innovative self-development of the company is one of the leading goals to which management efforts should be directed.

There are the research directions, determined as relevant, such as the issues of innovation activity management of enterprises, which necessitates the formation of a scientific and methodological basis that can realize the ability to describe the process of innovation activity of the enterprises and mechanisms to manage them. These issues are also relevant because in the context of strengthening the course on European integration, the management of domestic enterprises is tasked with identification of the methodological and practical experience of innovative management of the EU countries as soon as possible and harmonization of their policies in accordance with its provisions.

\section{Theoretical basis of the research}

Theoretical and practical researches of the innovation activity management of the enterprise are given in the works of many domestic and foreign scientists. For example, in the writings of N.P. Boretska, L.V. Petrenko the key problems that hinder the implementation of innovation operation of domestic enterprises are identified, the ways and directions of activation of innovation operation of theenterprises in Ukraine are suggested. In the works of A.K. Andriushko, T.V. Hrynko, H.V. Yermakova, V.O. Kasianenko, S.M. Illiashenko, A.Yu. Reustov, A.S. Chernov, J. Shumpeter, etc., conceptual bases of innovation development management of the enterprise are considered and theoretical principles and scientific-practical approaches to economic interpretation of process of innovation development management of the enterprise as systematic management of innovative activity are directed, aimed at formation and maintenance of achievement of economic growth through rational use, increase and distribution of innovative and technological innovation potential. The factors and tendencies of innovation activity of the enterprises are investigated, problems and prospects of activation of innovation and scientific and technical operation of the enterprises are determined. The most developed and widely presented topic is the organization of innovation processes. It must be admitted that despite the considerable number of works devoted to solving the problems of the innovation activity management of the enterprise, some of its aspects, including the formation of the innovation activity of the enterprise under self-development, have not received sufficient coverage in scientific research.

\section{The main directions of formation of the innovative-active enterprise under self-development}

In the modern sense of self-development, it is the development of the organizational system of the enterprise at the expense of internal potential and resources in accordance with its own program. Selfdevelopment involves the presence of own mechanisms at the enterprise.

Modern enterprises are able to manage selfdevelopment: from self-development as a condition of survival of the enterprise to innovation selfdevelopment of the enterprise as a condition of sustainable competitive advantage in the market.

One of the main indicators of economic development of the country is the level of innovation activity of the enterprises. Today, it is widely recognized that innovation is part of an overall enterprise strategy aimed at achieving its relevant position in the industry. This approach is in line with J. Schumpeter's view of the dual nature of competition: as an organizing or creative force and as a disorganizing force in the form of "creative destruction" (Schumpeter, 1995). As a result, competition as a dynamic process contributes to the emergence of new technical and technological solutions, new products, forms of production organization, and sources of raw materials. In a market economy, firms make strategic decisions about financing research, and bear the risk of the consequences of implementing investment decisions.

The degree of innovation activity of enterprises and the nature of innovation are largely determined by the competitive structure of the industry. The latter determines the degree of competition intensity, the presence of entry barriers to the industry, the ability to accumulate financial resources for R\&D (Research \& Development), the ratio of autonomy in innovation operation and imitation.

The problem of innovation activity of enterprises in the Ukrainian market today has another important aspect. The decline in business activity experienced by the domestic economy is usually accompanied by a reduction in the cost of developing innovations. However, an analysis of the performance of large firms, especially in the oligopolistic markets, both high-tech and less technologically advanced, shows that for many of them, investment in R\&D remains a priority even in times of adverse economic conditions. This allows to achieve strategic benefits, enter new markets and consolidate your position in the industry after the crisis (Kovtunenko, Maslennikov, 2017). 
An enterprise is considered to be innovative-active if it: constantly improves and updates its products; acquires, develops and uses progressive machinery and advanced equipment; takes advantage of specialization and diversification; updates the raw material base through the use of higher quality and new raw materials; develops and refines the R\&D sector; introduces more sophisticated (high) technologies into the production process; introduces changes in the composition of functions, methods of operation of the control apparatus, in particular, applies automated control systems; improves the structure of personnel using highskill work; introduces the latest methods of organization of production and labor; uses new energy sources and energy-saving technologies; improves organizational structure; implements financial innovations; enhances the logistics chain; applies the latest marketing technologies; introduces environmental innovations (Andryushko).

From the point of view of improving the production process, it is necessary to refer those who take advantage of specialization and diversification to innovativeactive enterprises. In practice, enterprises specialize in the production of products that are in demand. The consumer can express his/her requirements for the product; in this case, production will be based on special orders. Enterprises can be transformed into complex multi-purpose complexes characterized by high resilience in the face of changing demand (Lohvynenko, Kuz'menko, Plentiov, 2010).

Among western economists, there is especially noted the approach of I. Ansoff to determine the activity of the organization. Based on his research, the scientist argues that the competitive status of the firm in the strategic area of management is determined as a result of the interaction of the following three factors: the effect of the scale of the organization, the competitive strategy, the potential of the organization (Organization for Economic Cooperation and Development; Reustov, 2011). At the same time, each of the above factors is not potentially possible, but already achieved by the organization as a result of revealed by its employees and leadership activity. Thus, according to I. Ansoff, the potential competitive status of the organization becomes real only in the case of non-zero activity, which is manifested by the firm (Reustov, 2011).

The Russian researchers (V.P. Barancheiev, N.P. Maslennikova, V.M. Mishyn) give the definition of innovation activity as a complex internal characteristic based on the properties, abilities and competencies of the organization as a consumer and supplier of an innovation product. This group of scientists looks at innovation activity from the standpoint of the so-called "black box" method, on the basis of which they have identified the key characteristics of an organization's innovation activity to which they belong: innovation receptivity, resource availability, quality of organization and communication and innovation competence (Hryn'ko, Yermakova, 2011).

Innovation activity is a distinctive feature of dynamic realization of a set of purposeful processes, which, due to the introduction of innovation transformations taking into account the interaction of factors of the external and internal environment, provide enterprise with certain competitive advantages. That is a complex characteristic of the innovation activity in the dynamics (Yastrems'ka, 2014).

Chernova A.S. defines the innovation activity of a firm as a complex characteristic of its innovation operation, the main aspect of which is susceptibility to innovation, based on competence in the issues of progress in this form (Chernova, 2015).

Thus, innovation activity is a dynamic, purposeful operation to create, develop the product, process, organizational and management innovations in the production and market in order to obtain the commercial benefits and competitive advantages of the innovativeactive enterprise. From this point of view, an innovation enterprise is considered an enterprise that develops and uses new or improved products, technological processes and other types of innovation operation.

The experience of developed countries shows that the distinguishing feature of innovation from scientific and technical operation performance lies primarily in the resources that need to be allocated to these goals. If, on average, the cost of basic research is taken as one, then the cost of applied research and development work exceeds 10 times. Realization of innovations (creation of new or improved product in the industry, development of new technological process and conquering of markets) requires investments in 2 times more that it is. With a united strategic goal, a competitive economy, high quality of life and national security - scientific, technical and innovation policies, differ in strategic objectives and ways of solving them. If the main task in science and technology policy and activity is to create scientific and technical units for the future, in particular long-term, then the task of innovation policy and operation is to use the developed array of knowledge and technologies today (Illyashenko, 2019).

Recently, the level of innovation activity of enterprises remains low. Among the factors hampering the implementation of innovations are lack of own funds, insufficient financial support of the state, high costs for innovations, high economic risk.

Ukraine, abandoning the direct and indirect stimulation and regulation of scientific and technological progress, without defining the development benchmarks for the future and the current moment, without becoming a customer and the main consumer of new (innovation) products of its enterprises, drove them into a dead end of technological backwardness, depriving them financially ensure production upgrades through a sharp reduction in investment in innovation (Borets'ka, Petrenko, 2019). 
Today, the own funds of enterprises remain the main source of financing innovations in the Ukrainian industry. In 2018 , their share was $88.2 \%$ of total funding. The predominance of the enterprises' own funds among sources of innovation financing is observed due to insufficient and difficult attraction of other resources (due to unfavorable investment climate, lack of venture capital, etc.).

The main source of financing for innovation costs is the own funds of enterprises: $10742.0 \mathrm{mln}$ UAH (or $88.2 \%$ of total innovation expenditures), compared to 2017 , they increased by $3.7 \%$; expenditures for innovations from the state budget amounted to $639.1 \mathrm{mln}$ UAH (5.2\%), compared to 2017, increased by $2.7 \%$; their total expenditures from the local budget amounted to only $13.4 \mathrm{mln} \mathrm{UAH}$ (0.1\%), compared to 2017, they decreased by $82.2 \mathrm{mln}$ UAH ( $86.0 \%)$; loans were used in 2018, compared to 2017, by $120.5 \mathrm{mln}$ UAH (20.3\%). In 2018, $84.4 \%$ of innovative-active industrial enterprises implemented innovations (or $15.6 \%$ of surveyed industrial ones). They implemented 3843 innovation products, which is 1456 units more than in 2017, 920 of which are new types of machines, equipment, appliances, apparatus and more. There are 2002 units implemented for the production of new technological processes in 2018 in comparison to 2017, their number increased by 173 (9.3\%). In 2018, 739 innovation enterprises sold innovation products for $24.9 \mathrm{bln} \mathrm{UAH}$, that is up $7.2 \mathrm{bln} \mathrm{UAH}$ more than in 2017 (Public Service of Statistics, 2019).

In addition, financing of the innovation activity of the enterprises in Ukraine is also characterized by low use of credit levers for its expansion. While innovative projects tend to be long-term and require significant investment in implementation, credit is generally provided for short-term and high interest rates (Illyashenko, 2019).

Among the factors, hampering the emergence of a high-tech economy, there is the low level of innovation infrastructure development. Firstly, there is no effective legal basis, since the few laws governing scientific and technical activities are inconsistent and contradictory. Secondly, the system of state institutions designed to regulate and stimulate innovation development is extremely flawed, as the existing structures duplicate each other, while most of the R\&D incentives remain uncovered (Zamryha, 2014).

There is a need to identify key problems associated with innovation in Ukraine.

The main problems can be attributed to the imperfection of the legislative framework of Ukraine, especially in the sphere of innovation activity and legal protection of its results. The disadvantage of the Ukrainian legislation is the lack of co-ordination of legislative acts among themselves and their inconsistency with the difficult economic situation in the country. The legal framework for regulating innovation activity in Ukraine is fragmentary, contradictory, which indicates its imperfection. The implementation of the adopted laws in the field of innovation is unsatisfactory. The current legislation is dominated by numerous normative legal acts. The problem is also the theoretical and legal substantiation of the concepts of modernization of the innovation system of Ukraine, as well as the definition of approaches and mechanisms for its implementation.

Restriction of sources of financing, which is related to financial and economic instability in the country, crisis of most enterprises and hostilities in the east of our country. Lack of own funds from enterprises for financing innovations is caused by high interest rates, inability to obtain long-term loans, massive bankruptcy of banks, etc. All this is one of the restraining factors for the innovation activity of the Ukrainian enterprises (Kas'yanenko, 2019).

Taking into account these problems, it is possible to determine ways and directions of activation of innovation operation in Ukraine:

- formation of a qualitatively new organization of relations and interaction between all participants of the innovation process, establishment of new functions by the relevant governing bodies both at the state and regional levels;

- the creation of an innovation product market, at which an adequate level of intellectual property protection must be ensured;

- preferential taxation of innovation companies, full or partial reimbursement of state expenditures for the development of innovations, participation in special state aid programs for the implementation of innovations, state orders for innovative products;

- creation of an effective system of innovation lending (application of lending to small innovative enterprises under guarantees of large enterprises, reduction of interest rate on innovation loans);

- granting interest-free loans or preferential loans to small enterprises engaged in scientific development;

- using the experience of developed countries, where lending and investing of small businesses with so-called "business angels", i.e., entities of small risk capital, hoping for a multiple increase in investment (Bilovods'ka, 2018).

- expansion of the resource base in the banking system, which will lead to efficient use of credit resources not only for replenishment of working capital, but also for the implementation of innovative projects by small businesses, etc.;

- motivation of innovation operation of enterprises by the state in the ways of training of personnel, managers of innovation activity, in the structure of the enterprise of inclusion of innovative-informative centers, introduction of electronic communications, programs of wide involvement of employees with creative thinking; - implementation of, first of all, scientific developments of domestic scientists;

- active cooperation of the authorities both among themselves, as well as with the entrepreneurial, scientific 
and business education sectors of the national economy (Borets'ka, Petrenko, 2019).

\section{The process of the activity management of the enterprise under self-development}

Improvement of the innovation activity management system is an integral part of the innovation management process as a whole and is a system of management decisions aimed at creating conditions conducive to innovation self-development and a state of components of innovation potential that corresponds to effective innovation activity.

The key aspects of improving the management system are highlighted: analysis and evaluation of changes in the operation of the enterprise (evaluation of innovation activity); choice of direction of innovation development of the enterprise; development of strategy of innovation operation (definition of priority of directions, their correlation, development of scenarios); control of implementation of the enterprise development strategy. The process of improving the enterprise innovation management system can be formulated in the form of a block diagram presented in Figure 1 .

Consider the process of managing the activity of the enterprise under self-development in accordance with the degree of self-development of the business entity (Akatov, 2012; Novikova, 2017).

The mechanism of the innovation activity management of the enterprise (Figure 2). With the purpose of formation of directions of improvement of the innovation activity management system it is possible to distinguish the following stages: analysis of components of the main indicators of innovation activity; assessment of economic development of the enterprise; analysis of the set of technical and technological developments in the field; evaluation of employees' qualifications; assessment of the base for R\&D.

The main task of management in the field of innovation activity under the enterprise's self-development is the continuous improvement of organizational and managerial potential, which ensures a high level of functioning of the enterprise in a changing external environment.

In order to increase organizational and managerial potential, it is necessary to analyze the composition and structure of personnel; identify the areas of training and/or retraining of personnel; strengthen the work on increasing the number of patents, licenses and innovation developments implemented.

Management in the field of technical and technological potential includes ensuring the maximum compliance of the technical and technological level of production with the requirements of innovation development. To achieve this, it is necessary to: analyze the level of production equipment; to form a supply system; strengthen product quality management; increase the number of innovation developments implemented.

The choice of the direction of improvement of the innovation activity management system depends, first of all, on the priority sphere of operation of the enterprise. However, in the real world, there is practically no stable plan of action for enterprises, as it is constantly adjusted as a result of changing environmental needs.

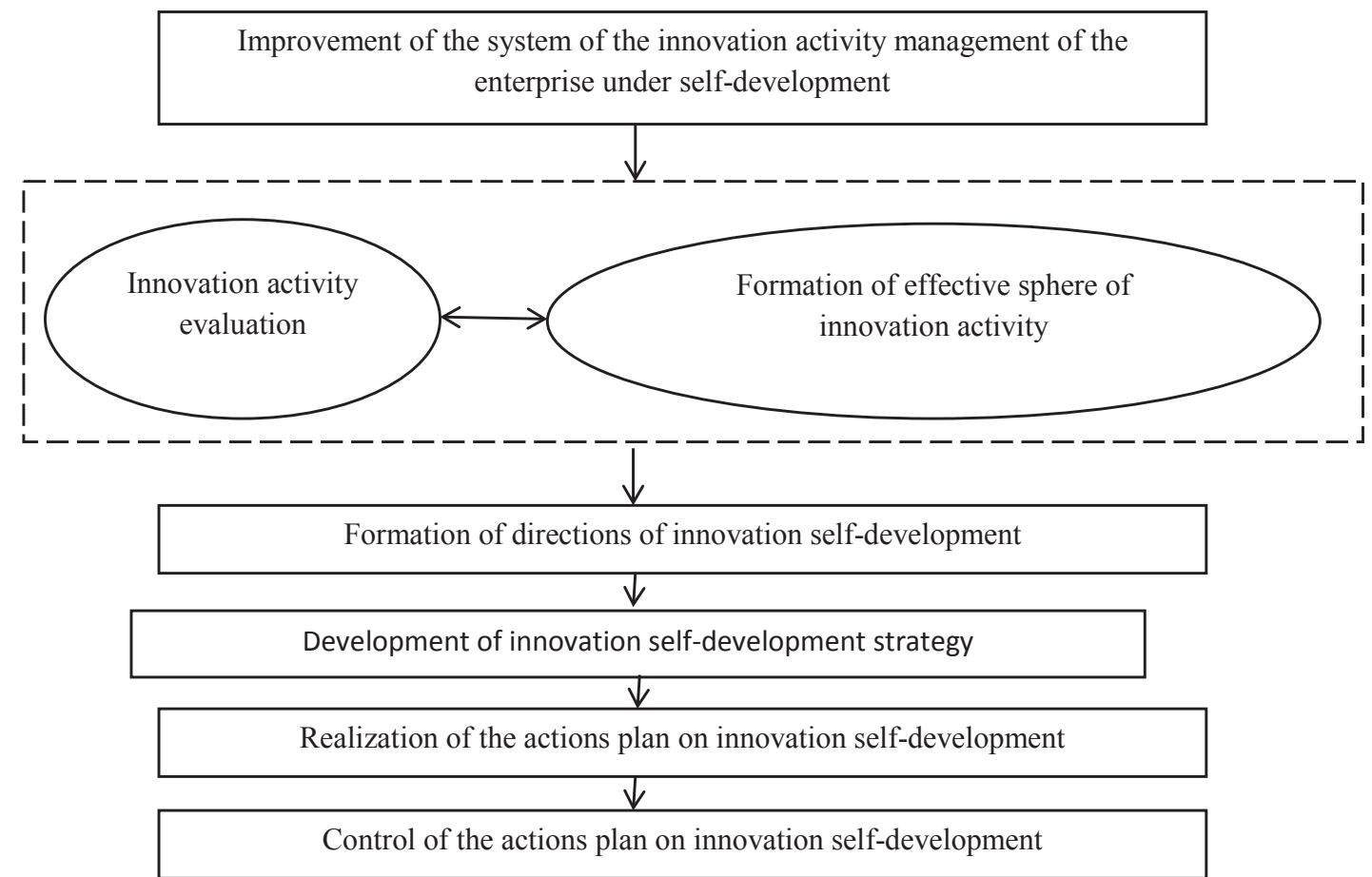

Figure 1. Block diagram of improvement of the activity management of the enterprise under self-development 


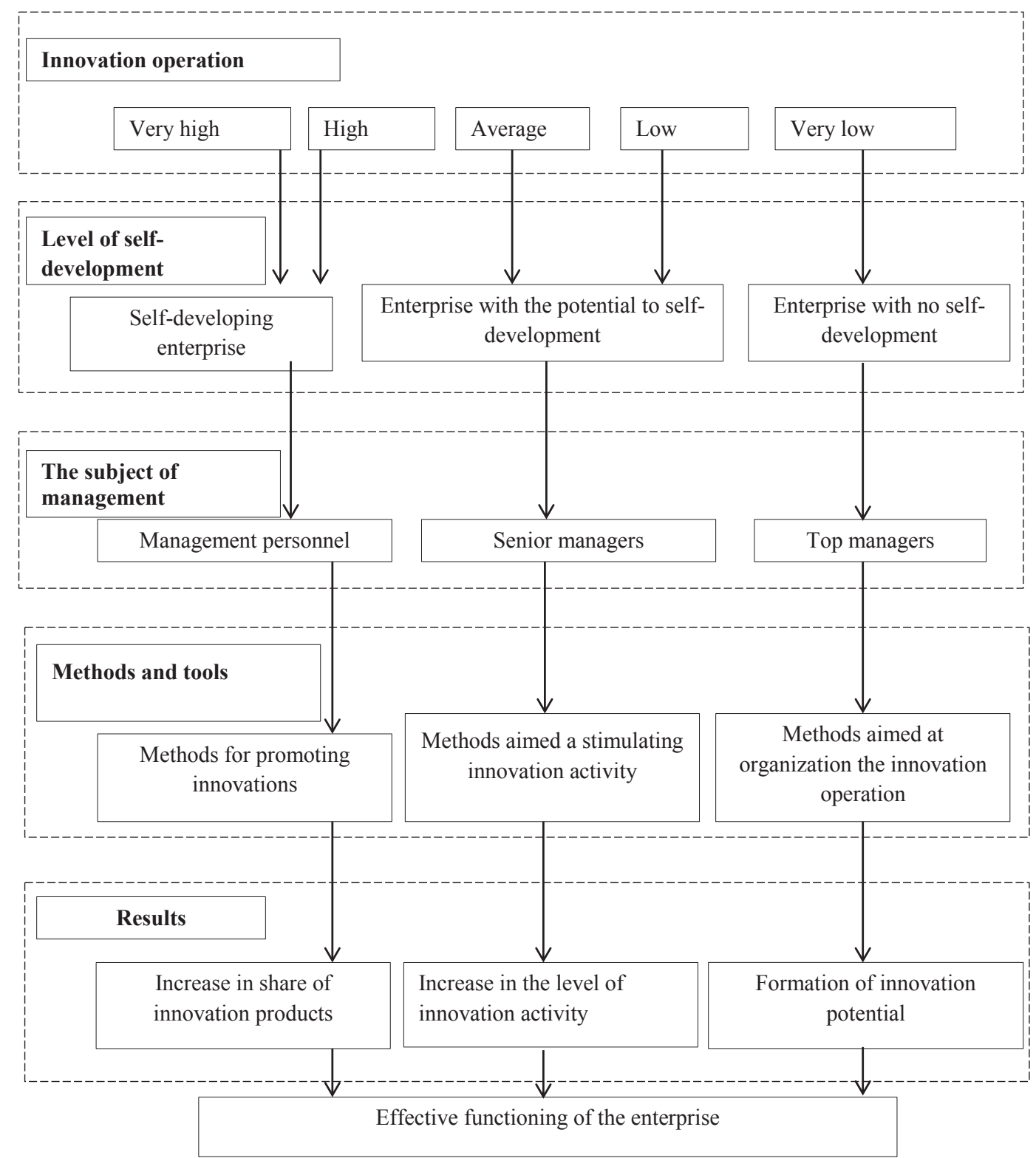

Figure 2. Mechanism of the innovation activity management of the enterprise under self-development

Source: developed by the authors according to (Akatov, 2012; Novikova, 2017)

\section{Conclusions}

The rapid development of the innovation sphere encourages enterprises to intensify their innovation activity, first of all, to form and retain competitive advantages and ensure the success of the enterprise. One of the state measures aimed at activating innovation operation in Ukraine should be to define this concept in the legislation and to develop indicators that would allow the analysis of innovation activity and identify the most effective directions of innovation development. The best for this, according to the authors, will be the application of the Mechanism of the innovation activity management of the enterprise under self-development.

In order to improve the innovation activity management system of the enterprise, a number of tasks can distinguish the solutions that will improve their development, such as:

- firstly, the focus on continuous innovation selfdevelopment;

- secondly, the innovation system management should be implemented as a process of creating innovations while making better use of the creative potential of the company personnel;

- third, the process of the innovation activity management should be taken into account when planning business development.

Given that the modern innovation process is complex, dynamic and global, it requires new indicators to shape effective innovation policy. The conducted researches of innovation activity management of the enterprise in 
the conditions of self-development, taking into account the practice of international comparisons to determine the effectiveness of innovation policy, show that its application allows to reveal both strength and weakness of measures aimed at forming the national innovation system.

\section{References:}

Akatov, N. B. (2012). Innovatsyonnoye samorazvitie organizatsii kak object upravlenia I kriterii konkurentosposobnostiv sovremennom menedgmentie [Innovation self-development of organization as an object of management and criteria of competitiveness in modern management]. Fundamental Research, no 11, pp. 744-749.

Andryushko, A. K. Innovatsiyno aktyvni pidpryyemstva: sutnist' ta faktory vplyvu na yih rozvytok [Innovation active companies: gist and impact factors of their development]. Available at: http://dspace.kntu.kr.ua/jspui/bitstream (accessed January 11, 2020).

Bilovods'ka, O. A. (2018). Marketinhova politika rozpodilu innovatsiynoyi produktsii promyslovyh pidpryemstv [Marketing policy of industrial companies' innovation products distribution]. Kyiv: Kondor. (in Ukrainian)

Borets'ka, N. P., \& Petrenko, L. V. (2019). Zahody aktyvizatsii innovatsiynoyi diyal'nosti pidpryemstva v suchasnyh umovah [Measures of company innovation work activization under modern conditions]. Business Navigator, no 5-1(54), pp. 94-99.

Hryn'ko, T. V., \& Yermakova, H. V. (2011). Sutnist' innovatsiynoyi diyal'nosti pidpryemstv ta yiyi otsinka [Essence of innovation activity of companies and its estimation]. Available at: http://archive.nbuv.gov.ua/portal/soc_gum/ bi/2011_11/62-64.pdf (accessed January 18, 2020).

Zamryha, A. B. (2014). Rol' finansuvannya v innovatsiynomu protsesi [Role of finance in innovation process]. Economic discours, no 2, pp. 117-121.

Illyashenko, S. M. (2019). Problemy upravlinnya innovatsiynym rozvytkom pidpryemstv u tranzytivnii ekonomitsi [Problems of companies' innovation development management in transitional economy]. Kyiv: Kondor. (in Ukrainian)

Illyashenko, S. M. (2019). Innovatsiynyi menedgment [Innovation management]. Kyiv: Kondor. (in Ukrainian)

Kovtunenko, K. V., \& Maslennikova, Ye. I. (2017). Innovatsiyna ekonomika: teoretychni ta praktychni aspekty [Innovation economy: theoretical and practical aspects]. Available at: http://dspace.puet.edu.ua/bitstream (accessed January 9, 2020).

Kas'yanenko, V. O. (2019). Innovatsiynyi potentsial ekonomiky Ukrainy: teoriya ta praktyka formuvannya otsinuvannya $i$ vykorystannya [Innovation potential of Ukraine economy: theory and practice of forming, estimation and implementation]. Kyiv: Kondor. (in Ukrainian)

Lohvynenko, Ye. I., Kuz'menko, O. M., \& Plentiov, M. V. (2010). Vyznachennya harakterystyk dlya opysu diyal'nosti innovatsiyno aktyvnyh pidpryemstv [Definition of characteristics for description of innovation active companies]. Available at: http://archive.nbuv.gov.ua/portal/soc_gum./VSUNU/2010_11_2/Logvinenko.pdf (accessed December 28, 2019).

Derzhavna sluzhba statystyky Ukrainy (2019). Naukova ta innovatsiyna diyal'nist' $v$ Ukraini u 2018 rotsi [Scientific and innovation activity in Ukraine in 2018]. Kyiv. Available at: http://ukrstat.org/uk/druk/publicat/kat_u/ publnauka u.htm (accessed December 28, 2019).

Novikova, O. A. (2017). K voprosu o vybore priopitetnyh napravlenii sovershenstvovania sistemy upravlenia innovatsionnoi aktivnosti promyshlennoho predpriyatiya [About a choice of priority directions of industrial companies innovation activity management improvement]. Internet-journal Naukovedenie (electronic journal), vol. 9, no. 5. Available at: https://naukovedenie.ru/PDF/95EVN517.pdf (accessed December 27, 2020).

Organization for Economic Cooperation and Development (OECD) and Statistical Office of the European Communities (Eurostat) (2005). [The measurement of scientific and technological activities: guidelines for collecting and interpreting innovation data]. Paris: Oslo manual.

Reustov, A. Yu. (2011). Analiz resursnoi, rezul'tatnoi I statisticheskoi component innovatsionnoi activnosti organizatsii [Analysis of resourse, result and statistical component of company innovation activity]. Innovations. Investments, (electronic journal), no. 33. Available at: www.uecs.ru/component/content/article/650 (accessed January 9, 2020).

Yastrems'ka, O. M. (2014). Upravlinnya zhyttediyal'nistu pidpryemst promyslovosti [Management of industrial companies activity]. Available at: http://www.repository.hneu.edu.ua (accessed January 12, 2020).

Chernova, A. S. (2015). Suschnost' innovatsionnoi activnosti predpriyatii [Essence of companies' innovation activity]. Molodoi uchenyi, no 1, pp. 311-312.

Shumpeter, J. (1995). Kapitalism, sotsialism i democratiya [Capitalism, socialism and democracy]. Moscow: Ekonomika. (in Russian) 